\title{
Mapping of Public Space for Cultural Celebration Chinese Ethnic in Chinatown Semarang
}

\author{
R. Kurniatia (ID , S. Soetomo a, I. Buchoria \\ a Department of Urban and Regional Planning, Engineering Faculty, Diponegoro University, Semarang, Indonesia
}

\section{Article Info:}

Received: 4 October 2017

in revised form: January 2018

Accepted: January 2019

Available Online: 1 December 2020

Keywords:

Public Space, Cultural Activities,

Chinatown

Corresponding Author:

R. Kurniati

Department of Urban and Regional

Planning, Diponegoro University,

Indonesia

Email: adalerina_66@yahoo.com

\begin{abstract}
Chinatown, often called Chinezen Wijk, is one of the centers of the city's economic activity. This area is developing very fast, plus the characteristics of worship activities and cultural celebrations that use public space in the form of roads, so that the area becomes crowded. Based on these problems, this study aimed to map the celebration of Chinese ethnic culture in the public space of the Semarang Chinatown. The research method is quantitative descriptive with GIS to map cultural celebration activities in the public space. The analysis results show that cultural celebration activities in the public space are influenced by the duration of the event, location selection, smooth traffic, parking conditions, and road conditions. The results of this study are expected to contribute to better spatial planning policy.
\end{abstract}

Copyright (C) 2020 GJGP-UNDIP

\section{INTRODUCTION}

The quality of urban space has been proved to provide social, psychological, and economic benefits (Do, Mori, \& Nomura, 2019) that contribute to the sustainability of urban development (Kim \& Kwon, 2018; Park, 2017). These urban spaces are then occupied by various age groups, sexes, cultural backgrounds, and social groups, each of these diversities requires space needs with different characteristics. In fact, the main purpose of the New Urban Agenda and Sustainable Development Goals is to ensure women's safety and inclusiveness in public spaces (Mahadevia \& Lathia, 2019). Besides improving our physical and psychological health, public spaces also play a large role in strengthening communities and making our cities and neighborhoods more attractive places to live and work (Rahayu, 2019), because most communities that interact are from a similar cultural background. This culture and behavior of the user community plays a major role in determining urban spatial planning (Tjahjono, 2014).

The development of community activities in urban space in addition to urbanization factors, the factor of globalization is also a determinant of the development of Asian cities today (Soegijoko \& Tjahjati, 2005). The globalization factor can cause an economic crisis and affect a lot of spatial and social patterns that affect the cities (Kara, 2019), which can cause a crisis of urban space development (Evers \& Korff, 2002). This happens because globalization increases conflict and disintegration of urban space growth for the benefit of commercial space and land grabbing by capital owners and other social problems as a result of the unified city growth. This can trigger degradation, increase urban socio-spatial inequalities, and increase social space conflicts that threaten the future of cities (Cohen, 2008; United Nations Development Programme, 1999; World Development Report, 2009).

Urban development is basically an accumulation of urban development that is organic, formed by the historical and socio-cultural strength of its citizens who are unplanned or planned because of the results of urban space political policies (Kostof, 1991). A city as "human settlement" is not only a place to live but an activity space that has the role of encouraging empowerment to improve the welfare of its citizens 
(Serageldin, 1997; Wirotomo, 2004). The principle of sustainable global city growth is based on the appreciation of local values, principles of solidarity, and community empowerment (Serageldin, Cohen, \& Leitmann, 1995; Richards \& Hall, 2003; Schneider \& Susser, 2003). Individuals in the community create their own culture, according to Cristina De Rossi, an anthropologist at Barnet and Southgate College in London. Culture includes religion, food, style, language, marriage, music, morals, and many other things that form a group to act and interact. This is what can be seen in the culture of ethnic Chinese society (Zimmermann, 2015).

Chinatown is an area that shows market participants, parts of the region, and community build and negotiates the neo-liberalization process to strengthen urban development boundaries. Examples of Chinatown in Chicago and New York City that have historically been rooted in community resistance, a microcosm appears for economic purposes, so communities can produce and repackage culture and tourism to improve the superiority of a city (Nguyen, 2011). In the complexity of today's urban political economy, Chinatown appears as a critical representation that displays culture and economics in the unity that forms the contemporary urban landscape in the United States. Market participants, countries, and communities form a cultural enclave. This idea arises from market desires that require openness, competition, freedom from all forms of state intervention and represent the mechanism of economic growth (Harvey, 2007).

Chinatown has historically been a permanent fixture in every urban landscape in almost all cities in the world. New York, San Francisco, Boston, Los Angeles, Chicago all have an area known as Chinatown. Almost every big city Indonesia also has a Chinatown area built as a place of residence for Chinese people who worked in the trade sector during the Dutch Government (Mandasari, 2013). The physical environment of the Chinatown is often a highly contested location. On the one hand, there are economic aspirations of investors who want to form and sell ethnic city flavors to tourists and other residents, while on the other hand, there are needs of community members who live and work in them (Liu \& Geron, 2008). One example of the realization of the idea of this cultural sale was carried out in 1990 when the George Bush administration used Houston as a destination site during the World Economic Summit, followed by a Chinatown redevelopment plan based on the idea of the Houston convention that people would be interested in the atmosphere of a 'world city 'provided by Chinatown (Lin, 1995).

Changes in the nature and diversification of ethnic enclaves are also challenges that must be considered by the local government because conflicts can occur, but may be different from the stronger Boston Chinatown area (Liu \& Geron, 2008). By taking the example of Chinatown in Chicago and New York City, which has historically been rooted in community resistance, a microcosm emerged that for the economic benefit of the community can produce and repackage culture and tourism to improve the superiority of a city (Nguyen, 2011). Semarang is one of the cities that has Chinese ethnic settlements or often called Chinatown. The Chinatown area is one of the cultural conservation areas that still have much Chinese cultural heritage. The Chinatown area has historical value for the development of the city physically and socially (Kurniati, 2001).

One of the historical areas included in the list of heritage Conservation in Semarang City is Semarang Chinatown (Based on the Decree of Semarang's Mayor No.650/157, 2005). Chinatown area, with its cultural and architectural richness, has an important role in the development of the city (Prabowo, Widiastuti, \& Bramiana, 2017). Major religious events such as Poo Seng Tay Tee's birthday celebration, Kim Sin Wu, Kongco Chen-jen, Poo Sing Tay Tee or God of Medicine, Zheng He I Celebration commemorates the arrival of Sam Poo Tay Jhien statue on Semarang sea coast, Sejit Hok Tek Tjeng Sien celebrated by the Chinese Buddhist community. Other major events such as Sin Tjia or Chinese New Year are also held every 15 months 1 in the Chinese calendar.

The big events of this ethnic Chinese culture require extensive locations for parades, markets, and ethnic Chinese cultural arts. Because public space that is very much needed by the community is not found in Chinatown, so it uses space around the temple and on the road (Suliyati, 2007). Likewise, the Sam Poo Tay Jhien celebration, people will worship and sow flowers, usually a procession from Tay Kak Sie temple to Marina beach and then returns to Tay Kak Sie temple again, this celebration features some interesting cultural entertainment such as Wushu, Gambang Semarang and "Yangkim" music (www.aspertina.org, n.d.). The Sin Tjia event or the Chinese New Year event also uses Gang Wotgandul Timur road and Gang Pinggir as 
the Semawis Imlek Market bazaar. Chinese ethnic-religious events are divided into two parts, namely daily religious activities and religious activities on religious holidays.

Previous studies on China Town focused more on the role of Chinatown in the development of aspects of Chinese culture in various parts of the world (McCartney \& Chen, 2019; Thomson, 2019). In addition, research on the history and development of Chinatown as a center for Chinese culture in big cities has been more dominant in the last 5 years (Jian \& Gaofeng, 2019; McCartney \& Chen, 2019; Shah, 2019). From this gap, this research chooses to focus on mapping Chinese cultural attractions as one of the attractions in urban areas, especially in Indonesia. Therefore, this study is intended to map the celebration of Chinese ethnic as the cultural attraction in the Public space of Semarang Chinatown.

\section{DATA AND METHODS}

\subsection{Survey and Respondents}

The method used is a descriptive quantitative method. This research was descriptive, trying to convey the existing problem solving based on the data, also presents the data, analysis, and interpretation (Sugiyono, 2010). Respondents are people who live and move in the Chinatown Semarang. The population in Chinatown around 970 inhabitants. There are 3 Community Association (in Indonesia A.K.A RW), RW $2=331$ people, RW $3=362$ people and RW $4=277$ people. The determination of the questionnaire respondents in this study is to use a proportional sampling technique (Table 1 ).

Table 1. Distribution of Respondents

\begin{tabular}{|c|c|c|}
\hline No. & Location & Number of Respondents \\
\hline 1. & RW 2 & 31 \\
\hline 2. & RW 3 & 33 \\
\hline 3. & RW 4 & 26 \\
\hline \multicolumn{2}{|c|}{ Total } & 90 \\
\hline
\end{tabular}

The analysis technique used is the quantitative and descriptive method using analytical tools that correlate public space and utilization of public space by using spatial analysis (GIS). For descriptive methods used in the analysis of the characteristics of the use of public space and correlation of religious activity in public space. Having known the correlation between religious activities with public space, then mapping and overlaying the map so clearly visible areas with the densest activities can be given recommendations to parse the density of these activities.

\subsection{Public Space and Activities in China Town of Semarang City}

Chinatown area which is located in the Central District of Semarang. Chinatown is located between the Kelurahan Kauman and Kelurahan Kranggan in the Middle District of Semarang. Semarang's Chinatown neighborhood is bounded by Gang Warung, Pekojan, Semarang River's, Beteng street, and Pedamaran (Figure 1).

\subsubsection{Street}

Becoming one of the public space, as well as urban transport infrastructure, the road is also one that can be used freely and do not need any charge if used. The road is not only used as motor vehicle traffic lanes and non-motorized vehicles in Semarang's Chinatown area but is often used as a location for parking, even the location of the big day (Figure 2). This is due to the public space needed by the people in the Chinatown area to perform religious festivities that are not available, so the alternative utilization of existing public spaces for religious activities is the road. Chinatown neighborhood with high trading activity affects the density, of course, can be seen from the number of trucks carrying goods that pass through and the activity of loading and unloading of goods. In addition, many stores do not have a parking lot led to the use of the road for this purpose.

The road is also used as a location for economic activity, namely, as the location of Gang Pasar Baru is a traditional market located along the road corridor Gang Baru, Gang Pasar Baru, so the name is taken from 
the location named the Gang Baru (Figure 3). This market does not function as a traffic lane, so the 4-wheeled vehicles can not pass into the road corridor is when the market is operating. The market usually operates from $5 \mathrm{am}$ to $5 \mathrm{pm}$. After $5 \mathrm{pm}$ people can go through this road by using vehicles as traders took care of merchandise. Gang Pasar Baru also has no parking area, so visitors who come and want to park their vehicles can use the parking area along Beteng Street and Gang Warung.

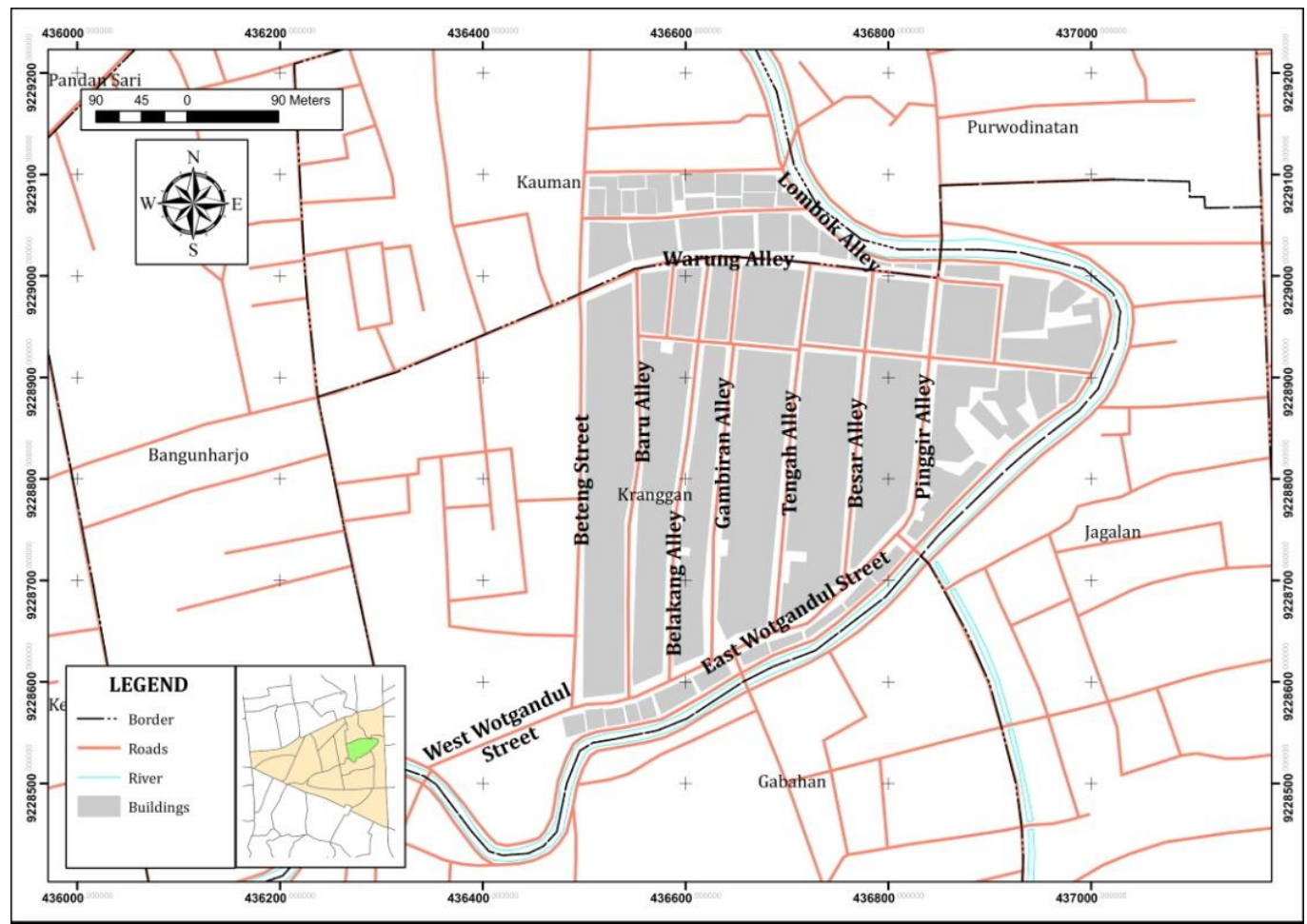

Figure 1. Semarang's Chinatown Area (Source: Bappeda Semarang, 2010)
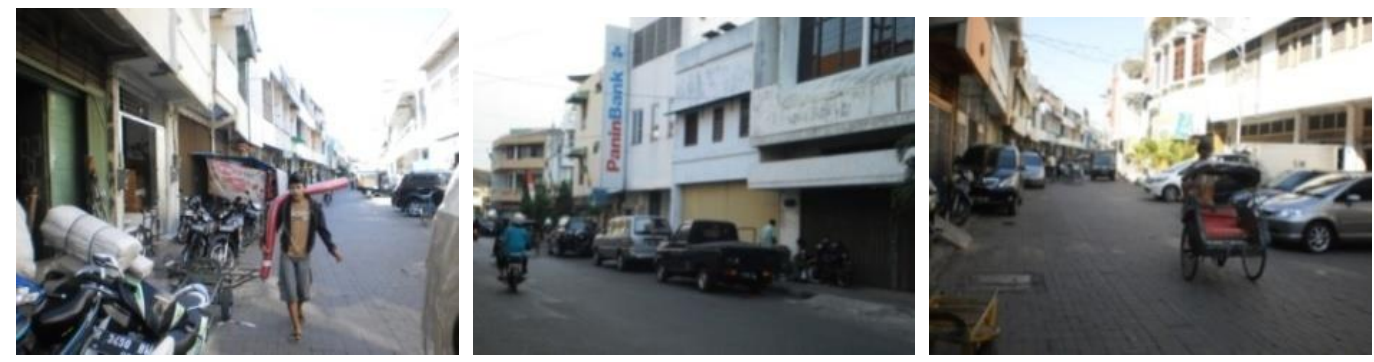

Figure 2. Utilized Streets as Parking Area (Sources: Observations, 2016)
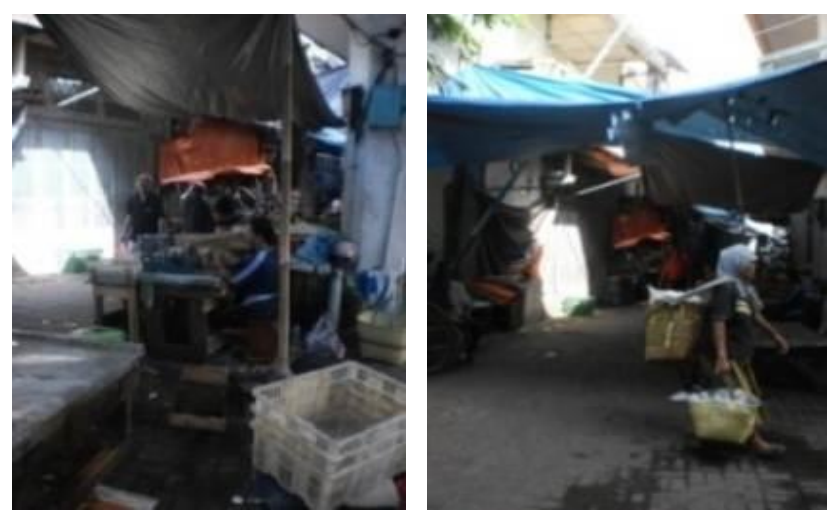

Figure 3. Utilized Gang Baru Street as Market Area (Sources: Observations, 2016) 


\subsubsection{Pedestrian Ways}

Pedestrian ways into the public space since become one of the infrastructure that can be used by the general public. In Semarang's Chinatown area, pedestrian ways are on the main roads, such as Jalan Beteng, Gang Warung, West Wotgandul, East Wotgandul, Gang Pinggir, the average width of 1-meter pedestrian ways. So that the circulation of people passing very narrow. In addition, pedestrian ways are also used as the location of street vendors' activity causes people not to use the path and choose to use the road (Figure 4).
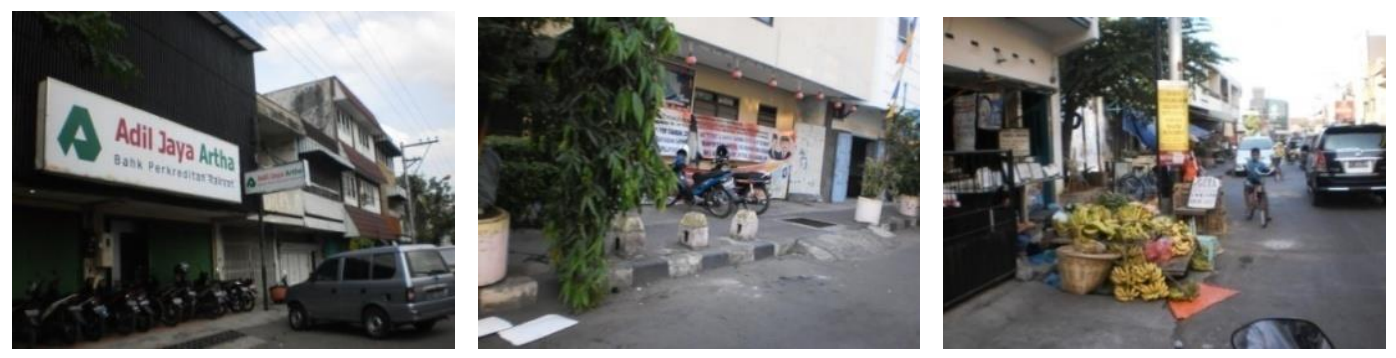

Figure 4. Utilization of Pedestrian Ways (Sources: Observations, 2016)

The pedestrian ways are utilized mainly according to its function. Parking and public space are not available required vendors to conduct their activities so that the community chose as the location of pedestrian activity. Utilization pedestrian ways do not fit this function causes people walking have to use the road. It will endanger pedestrians. In addition to pedestrian ways used by street vendors and motor vehicle parking location and track, conditions were rough and narrow pedestrian ways, and it made it uncomfortable for pedestrians.

\subsubsection{Waterfront Area}

Waterfront is an area adjacent to the waters. There are one or several activities in the area of the meeting (Rahman, Sastrawan, \& Soesanti, 2006). Chinatowns are restricted river or Kali Semarang Berok this waterfront neighborhood. Judging from the activity going on in the waterfront area utilizing public space during the day and night (Figure 5).
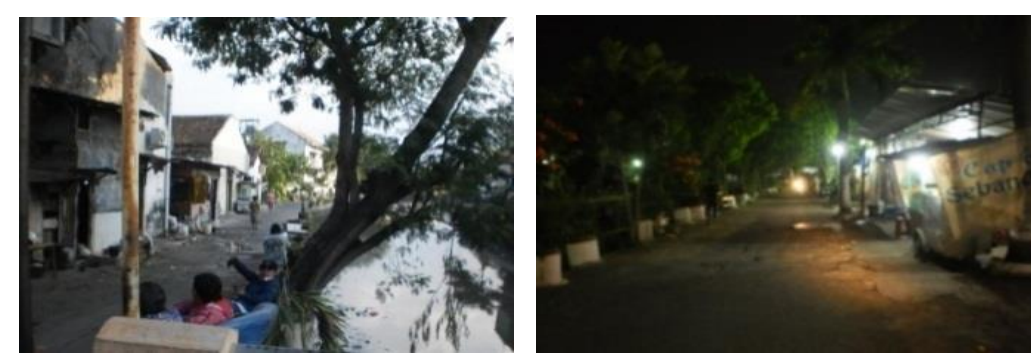

Figure 5. Utilization of the Waterfront on the day and night (Sources: Observations, 2015)

If seen from the image above in the daytime, in the waterfront area of Chinatown Semarang has not been to good use because Kali Semarang often smells due to the existing waste stream so that water does not flow properly. Sebandaran waterfront area on the way there is no activity, seen some people make the bench as a leisure place to interact with its neighbors, but also quiet with no activity. While in front of the Tay Kak Sie temple used for tourist activity. While at night, the street Sebandaran used as the location of street vendors hawking wares. The community takes advantage of this public space for activities, so the area is crowded. 


\subsection{Cultural Celebration}

\subsubsection{Small Sam Poo}

Small Sam Poo celebration to honor the arrival of the statue Cin Hio. This celebration is usually held by the Tay Kak Sie temple, with a carnival procession or small sampoo statue of Chinatown to the Marina beach and returned to Chinatown Semarang. The event also leverages the carnival procession path for bringing the statue to walk, so that there is the closure of several roads. This event started in the morning at 05.00, then the road closures began at 04.00 and opened again after the procession towards Marina Beach. Road closure performed again at 14:00 pm when a small sampoo statue arrived in Chinatown. A road closure adjusted route is commonly used in this event. Procession from Tay Kak Sie temple toward Gang Pinggir, East Wotgandul, Beteng, and West Wotgandul. So that the path to a fourth the road should be closed (Figure 6).
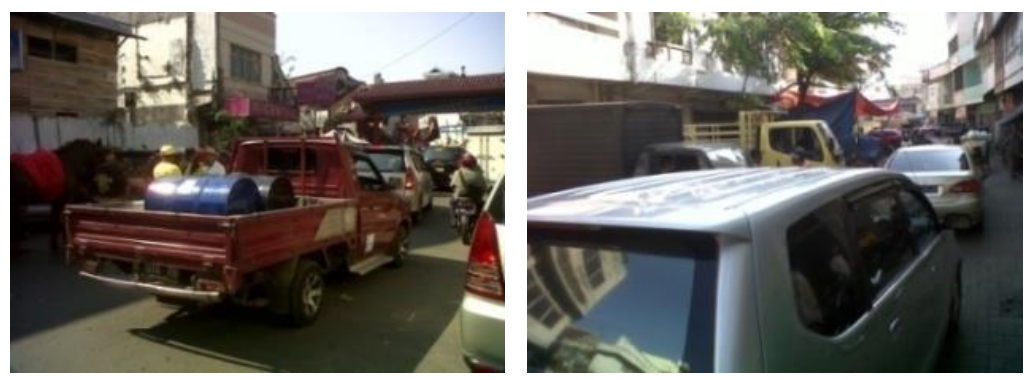

Figure 6. Congestion at the Celebration of Small Sam Poo (Sources: Observations, 2016)

\subsubsection{Great Sam Poo}

Zheng He I celebrations is a tradition of the procession Great Sam Poo to commemorate the arrival of the statue of Sam Poo Tay Jien at sea beach Semarang (Figure 7). This celebration is almost the same as the celebration of Small Sampoo, but the statue was brought larger and parade to the Gedong Batu, which is the location of a replica statue of Sam Poo Kong. After prayers at Tay Kak Sie temple, the next event is the procession ceremony of Kimsi, a sculpture departed from Chinatown to the temple area in Gedong Batu. Road closures are also made to support this event. These same carnival with Small Sampoo from Tay Kak Sie temple through road Gang Pinggir, East Wotgandul, West Wotgandul and Beteng Street.
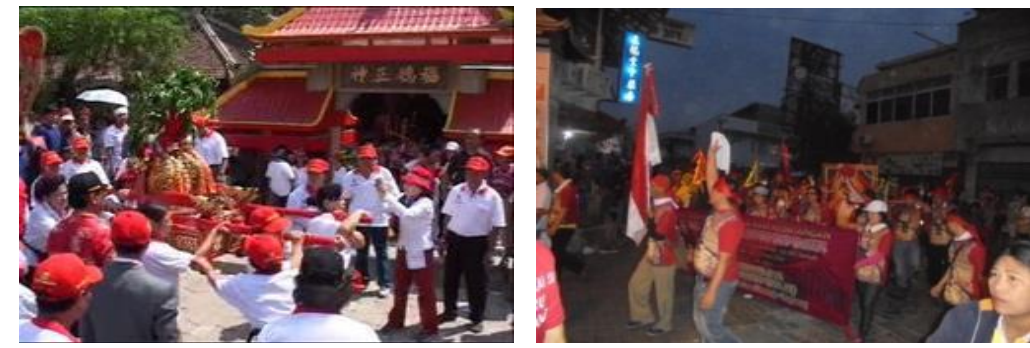

Figure 7. Zheng He I Celebrations/Great Sam Poo (Source: Observation, 2016)

\subsubsection{Chinese New Year Celebration}

The Chinese New Year celebration is celebrated by the ethnic Chinese community always accompanied interesting events in several major cities. Several years ago, it was determined that as the Chinese New Year holiday, the celebration of the Lunar New Year celebrated by members of the Chinese community and the general public can enjoy. Bazaar Lunar selling food and souvenirs Lunar Chinese shades also feature the art of Chinese culture. Likewise, Semarang's Chinatown neighborhood every year always carried a Lunar New Year celebration using the road for such activities. Since 2003 held the celebration of the Lunar New Year on the street Gang Edge to Wotgandul East, then in 2010 was conducted in Gang Warung until Gang Lombok 
alone, then in 2011, moved in Gang Lombok until Gang Wotgandul East, and in 2012 changed again located in the Gang Warung also the location of the night market. Chinese New Year celebration switching locations affected due to the small visitor Lunar market at the time was in the alleyway to Gang Warung Lombok. But now back again like at the beginning of the implementation of the Chinese market that is in Gang Semawis until Wotgandul East Rand. Celebrations are held from morning 09.00 am until 22.00 pm, causing road closures and traffic diversion (Figure 8).
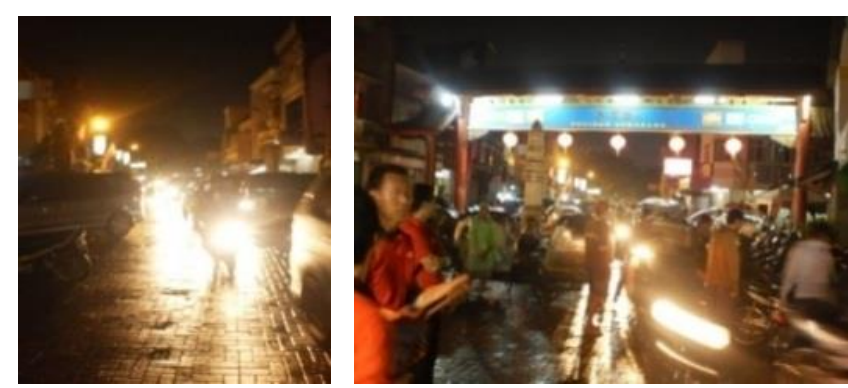

Figure 8. Congestion at The Chinese New Year Celebration (Sources: Observations, 2016)

\section{RESULTS AND DISCUSSION}

\subsection{Results}

\subsubsection{Traffic Congestion}

Congestion often occurs in Semarang's Chinatown area because the width of the road is limited. Likewise, when religious holidays, people who come to this region more than a typical day because of the people who followed the event not only of one ethnicity alone. As the Chinese New Year, the people who come not only ethnic Chinese communities, resulting in congestion due to visitors' vehicles.

Congestion is high enough to dominate the region by $90 \%$ (Figure 9). Congestion is caused due to the narrow width of the road and the number of vehicles that exceed the capacity of roads to accommodate motor vehicles, as this is the area of trade and motorcycles and cars, trucks transporting merchandise also dominate traffic in the region. On each occasion, a religious holiday always arises congestion, but the community is familiar with this bottleneck because it only occurs at certain points, such as on the street of Gang Warung and Wotgandul or points people to use public space for other activities, such as the time of Friday prayers on Beteng street and market location of Gang Baru.

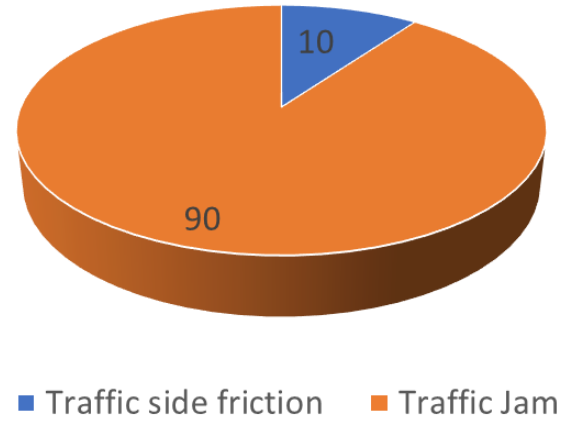

Figure 9. Traffic Flow At Celebration Events (in \%) (Source: Analysis, 2016)

\subsubsection{Economic Effects}

The economic effect is due to the effect of road use as religious holiday locations that require road closures to support the path of celebration. This economic influence affects less profitable for traders. 
Kurniati, Soetomo, \& Buchori / Geoplanning: Journal of Geomatics and Planning, Vol 7, No 2, 2020, 95-112

Street Vendors
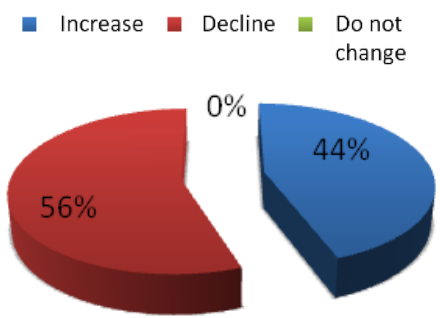

Trade

(wholesale, retail, warehouse)

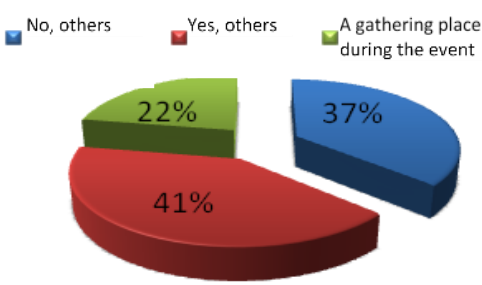

Figure 10. Economic Effects (Source: Analysis, 2016)

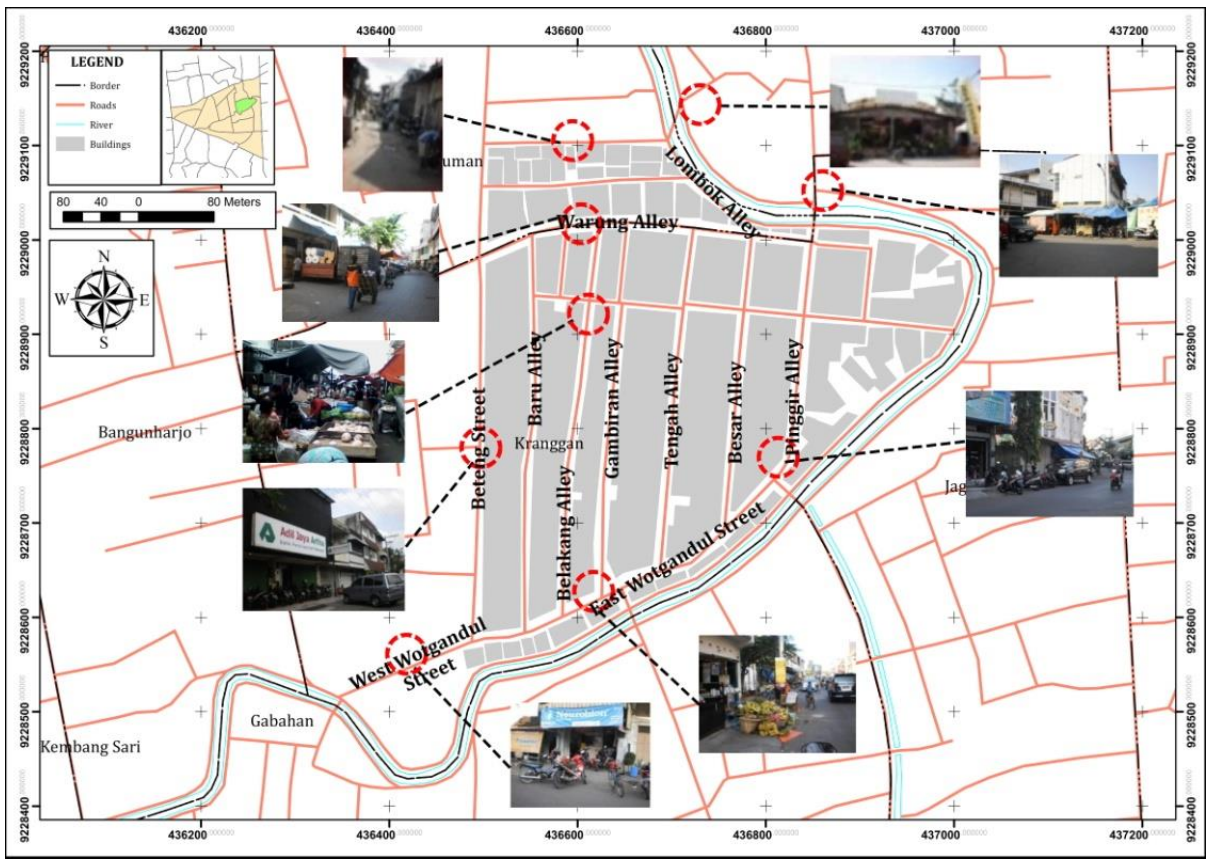

Figure 11. Mapping Economic Activities In Daytime (Sources: Observations, 2016)

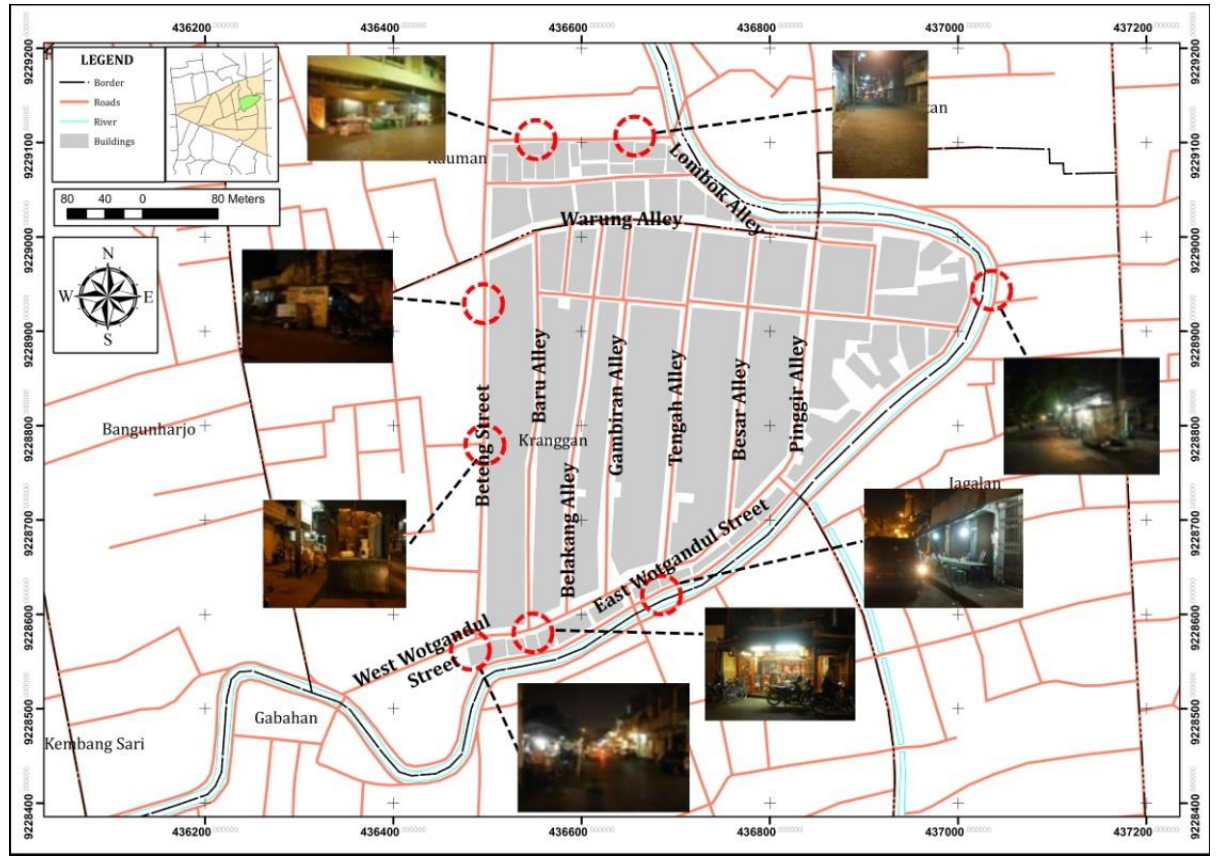

Figure 12. Mapping Economic Activities at Night (Sources: Observations, 2016) 
Traders vendors decreased turnover, around $56 \%$ losses because, during the event, there is no location for trade (Figure 10). The village rules asking the vendors did not sell at the venue religious holidays such as the Lunar New Year. Wholesalers, retail, and warehousing also decreased turnover due to road closures. The decline in turnover is because buyers are reluctant to come and prefer to find stuff elsewhere. But at this point, the community residents and businesses in the Chinatown area had received since the event took place only once a year (Figure 11 and 12).

The Activities for Religious Holiday Celebration (\%)

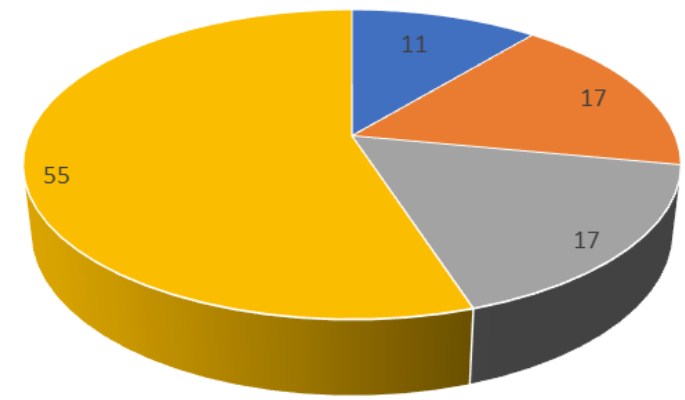

- Prepare The Places for celebration = Time for Celebration

- Stay in Gathering Places

- Community Interaction

Figure 13. Correlation of Neighborhood Community Social Interaction (Source: Analysis, 2016)

The effects in the social interaction of both categories. Chinatown community that most traders and is always busy at work so that they don't have time to interact with neighbors such as social gathering, or other associations, then this event is a great time to interact with their environment. They celebrate and participate in the event of a religious holiday. It is seen from the percentage of community interaction during the celebration of religious holidays by $55 \%$ (Figure 13). People were not objected to the use of public space as the location of the celebration and gathering place. The factors that most influence the accessibility of public space is the location of the celebration with a correlation coefficient reached 0.705 . There is a high correlation between the two variables.

\subsubsection{Celebrations Location}

People are much more frequent visits to show religious holidays Lunar New Year, the location of the celebration of Chinese New Year on the move does not reduce the interest of the public to come, the location on the street Gang (Figure 14-16). Just as the location of the market also sells equipment Lunar and often there are performances of puppet art potehi, Yankim, and gamelan are appealing to the public. On Chinese New Year public may attend, witness the art also interact with the surrounding community.

The choice of location affects economic activity because the celebration is on track and out of the area so that the road closures make lazy visitors come to the store subscription. This resulted in a decrease in the turnover of some traders in front of his shop is used for event celebration, including other services such as banks that were in that area customers reduced from days normally. 


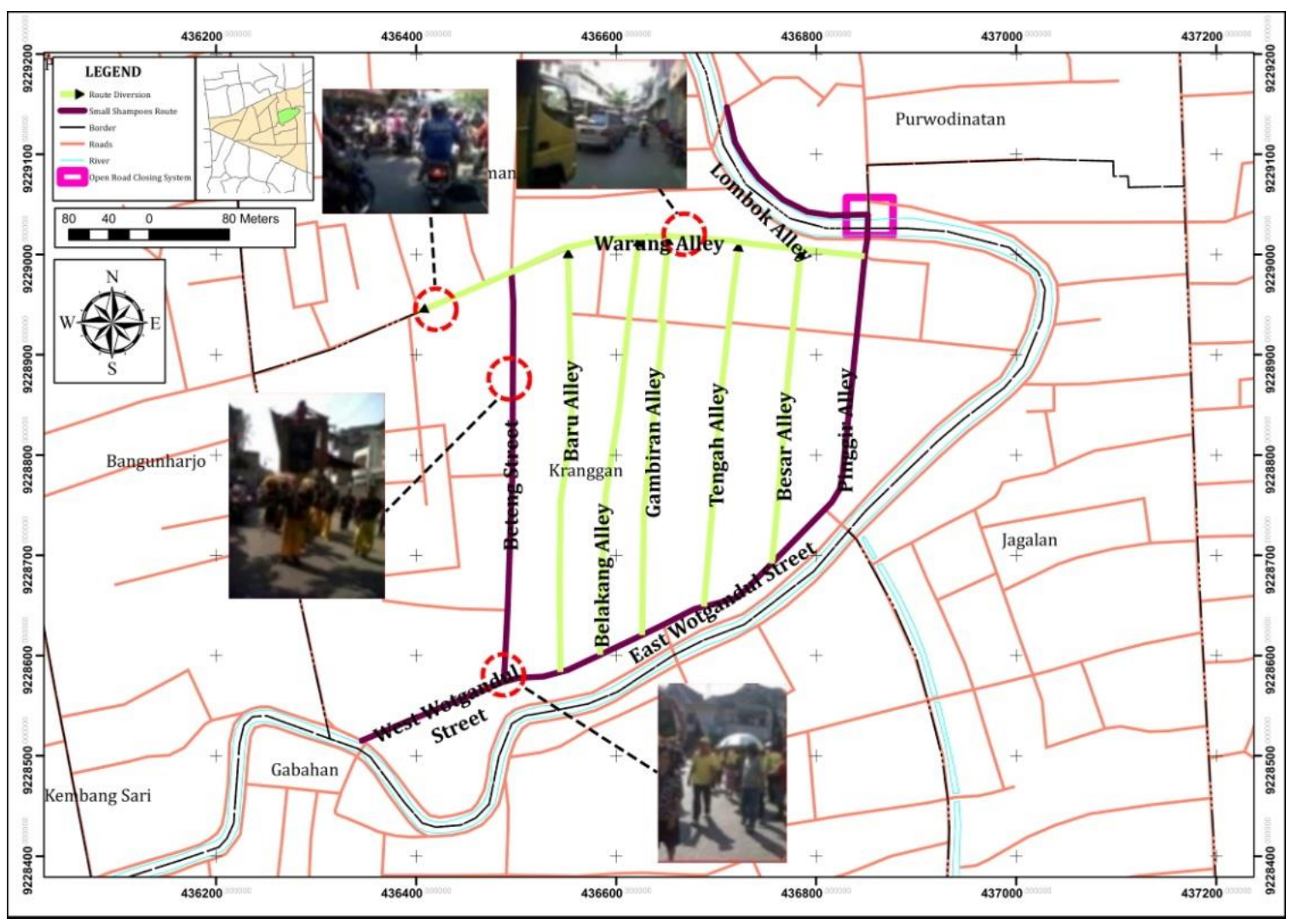

Figure 14. Mapping Route of Carnival Small Shampoos (Sources: Analysis, 2016)

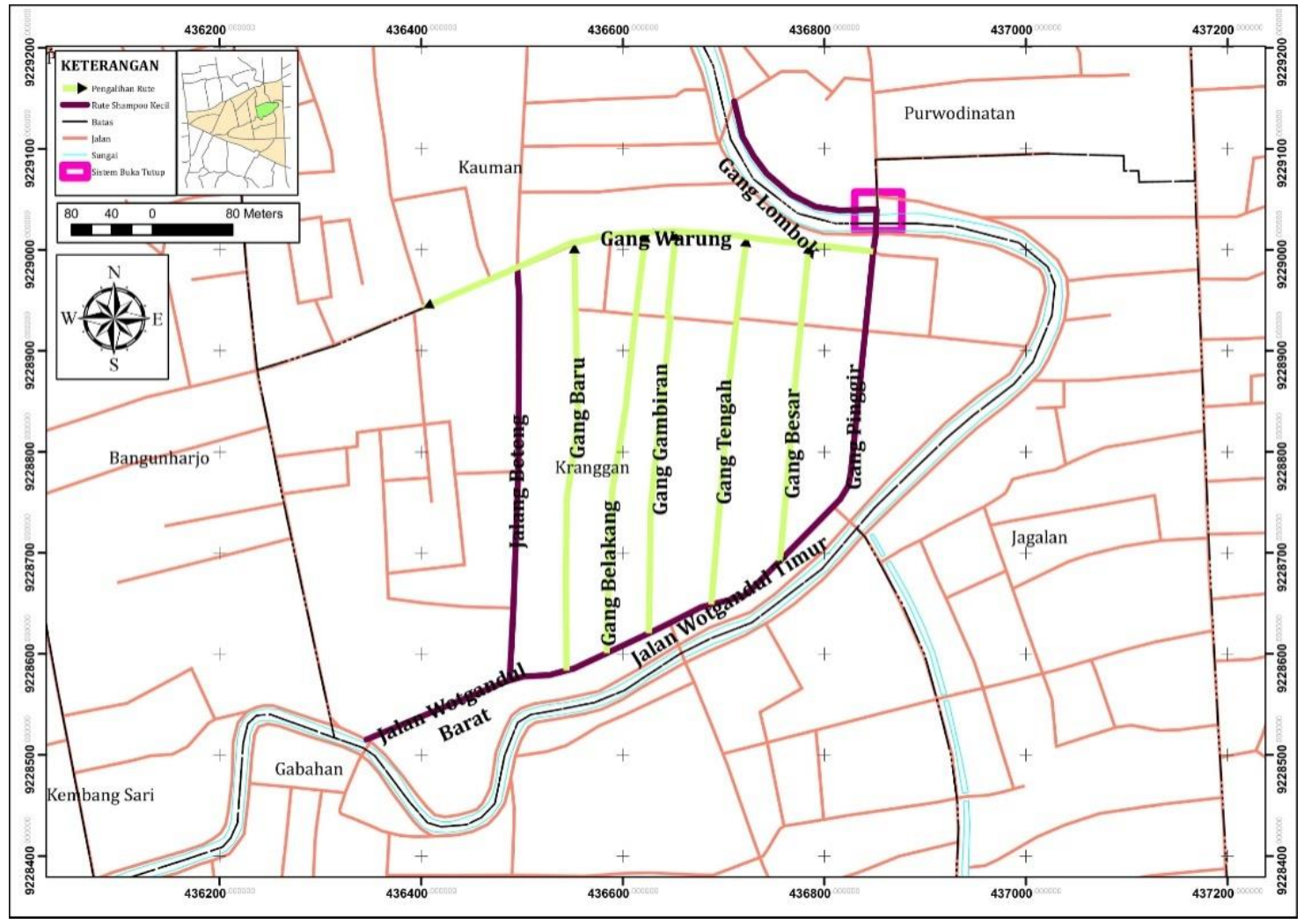

Figure 15. Mapping Route of Carnival Great Shampoos (Sources: Analysis, 2016) 


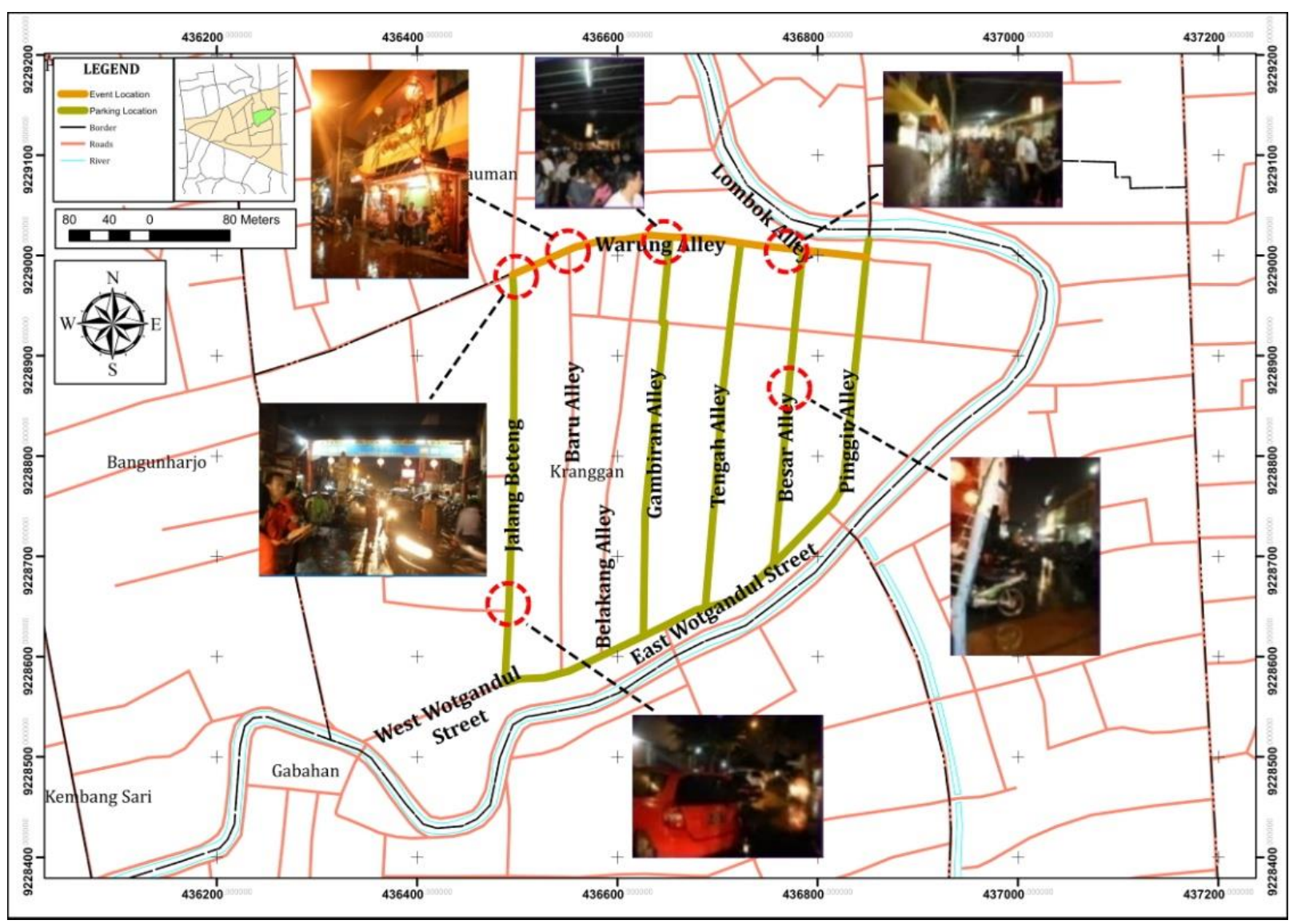

Figure 16. Mapping Usage Way For Chinese New Year Celebration (Sources: Analysis, 2016)

\subsubsection{Event Duration}

At the time of the small shampoo celebration, processional statues sampoo not done in a long time, because the show is done simply surround the major roads in the region, so as to avoid long traffic jams. Meanwhile, the location of the Lunar New Year Celebration in the Road Gang Rand to East Wotgandul by closing the road for three days. The alleys that surround the site used for parking of vehicles.

\subsection{Discussion}

\subsubsection{Public Space for Religious and Cultural Celebrations}

The public space for religious and cultural celebrations events needed a wide enough location, while the public spaces in the Chinatown neighborhood just a neighborhood street and Tay Kak Sie temple courtyard (Figure 17). So that the cultural space that is used to change and occupy the remaining open space. Therefore the information lunar new year celebrations are held around three today always include directions to the celebration so that people know its location. Directions are provided to allow people to reach the site.

Chinese New Year always shows bazaar and cultural performing arts requires a wide space for visitor circulation and other activities. Gang street baseboards and Wotgandul East as the location of the celebration with a road width of 8 meters can not accommodate the number of visitors. The duration of the event was also influenced by the road's width because the longer the event is executed, the space required more extensive, and visitors continued to arrive for circulation, eat, and shop.

In celebration of Small Sampoo followed by the carnival, has become an ancestral tradition that takes space that can be used. In the area of Chinatown, unavailable spacious public rooms to accommodate these activities, the road space used as a location for the celebration. Chinese New Year celebrations and the Great 
Sam Poo celebration take quite a long time using road space, resulting in road closures and traffic jams when the procession takes place.

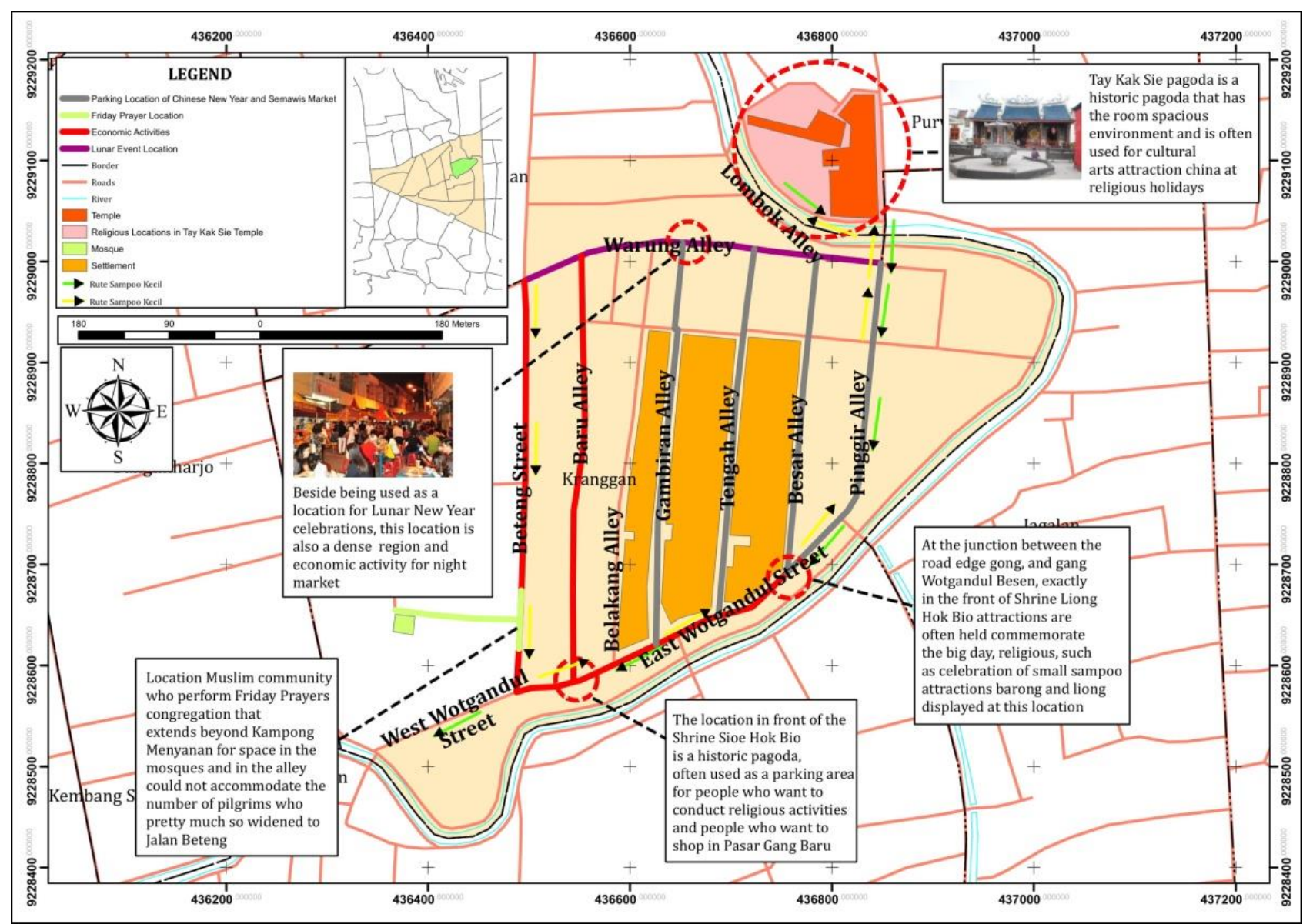

Figure 17. Overlay of Public Space for Religious and Cultural Celebrations (Source: Analysis, 2016)

\subsubsection{Daily Religious Activities in Public Spaces}

Daily religious activities in the public space are viewed from 4 things, namely location of worship, routine worship time, smoothness of daily traffic, function road. The following table of correlation as follows (Table 2):

Table 2. Daily Religious Activities in Public Spaces (Sources: Analysis, 2016)

\begin{tabular}{|c|c|c|c|}
\hline Variable & $\begin{array}{l}\text { Correlation } \\
\text { coefficient }\end{array}$ & Sig. Value & Take effect / no effect \\
\hline $\begin{array}{l}\text { Worship Place's Location with the } \\
\text { traffic smoothness }\end{array}$ & $\begin{array}{c}0.01 \\
\text { (Ignored) }\end{array}$ & $\begin{array}{c}0.924 \\
\left(H_{o} \text { accepted) }\right.\end{array}$ & $\begin{array}{c}\text { There is no correlation between } \\
\text { the two variables }\end{array}$ \\
\hline $\begin{array}{l}\text { Worship Place's Location with Road } \\
\text { Function }\end{array}$ & $\begin{array}{c}0.082 \\
\text { (Ignored) }\end{array}$ & $\begin{array}{c}0.445 \\
\text { (Hoaccepted) }\end{array}$ & $\begin{array}{c}\text { There is no correlation between } \\
\text { the two variables }\end{array}$ \\
\hline $\begin{array}{l}\text { Time of Worship Routine with the } \\
\text { traffic smoothness }\end{array}$ & $\begin{array}{c}0.121 \\
\text { (Ignored) }\end{array}$ & $\begin{array}{c}0.257 \\
\left(H_{\circ} \text { accepted) }\right.\end{array}$ & $\begin{array}{c}\text { There is no correlation between } \\
\text { the two variables }\end{array}$ \\
\hline $\begin{array}{l}\text { Time of Worship Routine with road } \\
\text { function }\end{array}$ & $\begin{array}{c}-0.075 \\
\text { (Ignored) }\end{array}$ & $\begin{array}{c}0.482 \\
\left(H_{\circ} \text { accepted) }\right.\end{array}$ & $\begin{array}{c}\text { There is no correlation between } \\
\text { the two variables }\end{array}$ \\
\hline
\end{tabular}

Seen from each significance, all have significant value $>0,05$, so it can be concluded that Ho accepted, so there is no relation between the location of the place of worship with the smoothness of traffic, no relation 
between worship location with the function of the road, time of worship with smooth daily traffic and worship time with road function. None of this relationship can be seen from the smoothness of traffic on a typical day. There is no traffic jam. There are sometimes side barriers due to the road function used for transportation infrastructure and parking lots and street vendors. So that regular religious activity does not affect anything in the public space around the Chinatown.

\subsubsection{Annual Religious Activities in Public Space}

Annual religious activity in the public spaces, viewed from 4 things that are the type of activities in a religious holiday day, the location of the celebration, the length of the event, and the reasons for choosing the place whereas in the dependent variable can be reviewed in 5 things: the smooth running during the event, the width of the road, the length of the road used and the parking conditions at the event, for more details below, is the table of correlation as follows (Table 3).

Table 3. Annual Religious Activities in Public Spaces (Sources: Analysis, 2016)

\begin{tabular}{|c|c|c|c|}
\hline Variable & $\begin{array}{l}\text { Correlation } \\
\text { coefficient }\end{array}$ & Sig. Value & Take effect / no effect \\
\hline Kind of religious big day with & 0.472 & 0.000 & There is a moderate correlation \\
\hline Celebrations Location & (Mid) & (HoRejected) & between the two variables \\
\hline Length of Event with Celebrations & -0.305 & 0.004 & There is a low correlation between \\
\hline Location & (Low) & ( $\mathrm{H}_{\circ}$ Rejected) & the two variables \\
\hline Reasons for Place Selection with & -0.705 & 0.000 & There is a high correlation between \\
\hline Celebrations Location & (High) & (HoRejected) & the two variables \\
\hline
\end{tabular}

Between the types of religious festivals with the location of the celebration has a moderate correlation relationship. The relationship can be seen from the type of religious holidays. Not all religious day activities are held in the same location. Approximately $65 \%$ of people visit more often during Lunar New Year religious festivities. There is an influence between the length of the event and the location of religious ceremonies, but the effect is still low. For example, during a small sampoo celebration, the procession of a statue of a sampoo is not done in a long time because the event is done around the major roads in the area. Suppose the road closures in a long period of time will cause more severe congestion. Meanwhile, the location of Lunar New Year Celebration, which is located in Jalan Gang Warung which is a dense activity only during day time but the night, the corridor of the road is deserted, hence the time of the religious event which lasts long enough almost more than 10 hours so that the traffic jam is only in the vehicle parking area only. So that anticipation of congestion can be arranged by arranging where the public space to be used with the duration of the utilization of the space.

There is a high influence between the reason for choosing the event location and the location of the event. Because $33 \%$ of people think that the selected location is a location that has an easy outlet, people are easy to move without vehicles or with vehicles. In addition, about $23 \%$ argued that the selection of the location was due to the absence of public space that could be used for the celebration of the religious celebration, thus using the highway as the location of the celebration. The influence that occurs on the selection of the event location with the celebration location in the road corridor has dense activity, so it influences the economic aspect because the location selection is in the dense area, so the closure of the road resulted in a decrease in the turnover of some traders whose shops including those affected by road closures. Not on merchants alone, even banks in the region are also affected, where customers are reduced from the usual days. 


\subsubsection{Variety of Communities Activities in Public Space}

A variety of community activities in public space influenced by daily religious day, event duration, choosing a place, traffic and parking can be seen in Table 4.

Table 4. Variety of Communities Activities in Public Space (Sources: Analysis, 2016)

\begin{tabular}{|c|c|c|c|}
\hline Variable & $\begin{array}{l}\text { Correlation } \\
\text { coefficient }\end{array}$ & Sig. Value & Take effect / no effect \\
\hline $\begin{array}{l}\text { Types of Religious Day Events With traffic } \\
\text { Smoothness during Event }\end{array}$ & $\begin{array}{c}-0.082 \\
\text { (Ignored) }\end{array}$ & $\begin{array}{c}0.445 \\
\left(\mathrm{H}_{\circ}\right. \\
\text { Accepted) }\end{array}$ & $\begin{array}{l}\text { There is no correlation between } \\
\text { the two variables }\end{array}$ \\
\hline $\begin{array}{l}\text { Length of Events with traffic smoothness } \\
\text { during the event }\end{array}$ & $\begin{array}{c}0.082 \\
\text { (Ignored) }\end{array}$ & $\begin{array}{c}0.442 \\
\left(\mathrm{H}_{\circ}\right. \\
\text { Accepted) }\end{array}$ & $\begin{array}{c}\text { There is no correlation between } \\
\text { the two variables }\end{array}$ \\
\hline $\begin{array}{l}\text { Reason for location selection with traffic } \\
\text { smoothness during the event }\end{array}$ & $\begin{array}{c}-0.074 \\
\text { (Ignored) }\end{array}$ & $\begin{array}{c}0.433 \\
\left(\mathrm{H}_{\circ}\right. \\
\text { Accepted })\end{array}$ & $\begin{array}{l}\text { There is no correlation between } \\
\text { the two variables }\end{array}$ \\
\hline $\begin{array}{l}\text { Types of Religious Day Events With parking } \\
\text { condition }\end{array}$ & $\begin{array}{c}0.181 \\
\text { (Ignored) }\end{array}$ & $\begin{array}{c}0.087 \\
\left(\mathrm{H}_{\circ}\right. \\
\text { Accepted) }\end{array}$ & $\begin{array}{l}\text { There is no correlation between } \\
\text { the two variables }\end{array}$ \\
\hline Length of Events with parking Condition & $\begin{array}{c}-0.06 \\
\text { (Ignored) }\end{array}$ & $\begin{array}{c}0.576 \\
\left(\mathrm{H}_{\circ}\right. \\
\text { Accepted) }\end{array}$ & $\begin{array}{l}\text { There is no correlation between } \\
\text { the two variables }\end{array}$ \\
\hline $\begin{array}{l}\text { Reason for location selection with parking } \\
\text { condition }\end{array}$ & $\begin{array}{c}0.003 \\
\text { (Ignored) }\end{array}$ & $\begin{array}{c}0.978 \\
\left(\mathrm{H}_{\circ}\right. \\
\text { Accepted) }\end{array}$ & $\begin{array}{l}\text { There is no correlation between } \\
\text { the two variables }\end{array}$ \\
\hline
\end{tabular}

According to the result of the correlation coefficient and significance, the value found that there is no correlation between the type of religious days, length of events, and reasons for location selection with traffic smoothness and parking conditions. Because the Chinatown area is an area with economic activity, crowds due to loading and unloading of goods that often cause congestion on weekdays or holidays do not disturb the community's comfort. People living in this area are dominated by people who work as traders. As stated by Do et al. (2019), urban space has been proved to provide social, psychological, and economic benefits, so people who are living in this area believe that more crowded the area means their economic activities more profitable and continue to run. It can be concluded that people do not feel disturbed by the congestion during the event because the area is a trade and service area, not as a residential area that should have a comfortable atmosphere.

\subsubsection{Location Selection for Celebration}

In this analysis, it can be seen from 4 things, the type of religious day, the length of the event, the reason for the location selection of celebration. The following is the result of the correlation as follows (Table 5). 
Table 5. Location Selection for Celebration (Sources: Analysis, 2016)

\begin{tabular}{|c|c|c|c|}
\hline Variable & $\begin{array}{l}\text { Correlation } \\
\text { coefficient }\end{array}$ & Sig. Value & Take effect / no effect \\
\hline $\begin{array}{l}\text { Types of Religious Days with Direction to } \\
\text { the celebration location }\end{array}$ & $\begin{array}{l}0.315 \\
\text { (Low) }\end{array}$ & $\begin{array}{c}0.002 \\
\left(H_{\circ} \text { Rejected }\right)\end{array}$ & $\begin{array}{l}\text { There is a low correlation } \\
\text { between the two variables }\end{array}$ \\
\hline $\begin{array}{l}\text { Length of events with Direction to the } \\
\text { celebration location }\end{array}$ & $\begin{array}{l}-0.393 \\
(\text { Low })\end{array}$ & $\begin{array}{c}0.000 \\
\left(H_{\circ} \text { Rejected }\right.\end{array}$ & $\begin{array}{l}\text { There is a low correlation } \\
\text { between the two variables }\end{array}$ \\
\hline $\begin{array}{l}\text { Reason for location selection with } \\
\text { Direction to the celebration location }\end{array}$ & $\begin{array}{c}-0.135 \\
\text { (Ignored) }\end{array}$ & $\begin{array}{c}0.203 \\
\left(\mathrm{H}_{\circ}\right. \\
\text { Accepted })\end{array}$ & $\begin{array}{l}\text { There is no correlation between } \\
\text { the two variables }\end{array}$ \\
\hline
\end{tabular}

When viewed from the correlation table above, it can be seen between the type of religious days with directions to the celebration location has a low correlation relationship. Meanwhile, there is a relationship between the length of the celebration with directions to the celebration location. This can be seen from the celebration of the Chinese New Year and the celebration of a small sampoo. Lunar New Year celebration, which is held around three days, is always equipped with directions to the celebration location because the show is long enough to cause people who want to come but do not know the location can know the directions. However, the directions are not easy to understand because $42 \%$ of the people find it hard to understand directions made to make it easier for visitors to reach the location.

Another case with small sampoo celebrations conducted by the procession is only one day and not settled, or the celebration is changing location, so directions are not needed because the location of the celebration is not centered at one point location because this event is a carnival event. In contrast, the correlation coefficient and significance value of the reasons of location selection with directions showed no relationship between the reasons for location selection with directions to the location of the celebration.

\subsubsection{Condition of Street Type for Celebration}

The type of religious days, duration of events, and reasons for location selection with the street width and the street length used during the event can be seen in Table 6. The table shows that on the influence between types of religious day and the width of the road used states that there is a relationship between the two variables. Because more religious festivals are using the road body so that the size of the required road width affects the type of activity. While the length of the event with the road width is also used, there is also a low relationship between the two. As the Lunar New Year celebrations that always display bazaars and cultural arts, it takes a large space to place booths peddling food and accessories and the need for space for diners and visitor circulation. The influence between the reason for location selection and the road width is not of great influence and can be ignored because Ho is accepted and there is no relationship between the reason for location selection and the width of the road.

While the correlation between the road length used with the type of religious days showed a low influence, another effect of the event's duration with the road length used in the event obtained the result that there is a relationship between the two. Because different types of events and event time difference will require the length of the road that will be used for the event container will also be different so that the type of event and the length of time of religious ceremonies also affect the length of the road used for the event. The difference in the length of the road used is also evident from the Great Lunar New Year Celebration and Celebration, where the length of the road used is quite different. When the time required for the celebration is long enough, then the length of the used road the smaller it can be concluded that the smaller the length of the road used because it wants to reduce the congestion problem that will be generated from the road closure. As in the Small Sam Poo celebration where the length of the road used is long enough, so the congestion can not be avoided in some traffic jams such as in Gang Warung and on the street where the 
procession is taking place. While on the reasons for location selection with the length of the road used, there is no relationship between the two.

Table 6. Condition of Street Type for Celebration (Sources: Analysis, 2016)

\begin{tabular}{|c|c|c|c|}
\hline Variable & $\begin{array}{l}\text { Correlation } \\
\text { coefficient }\end{array}$ & Sig. Value & Take effect / no effect \\
\hline $\begin{array}{l}\text { Types of Religious Days with the street } \\
\text { width used }\end{array}$ & $\begin{array}{l}-0.414 \\
(\text { Low })\end{array}$ & $\begin{array}{c}0.000 \\
\left(H_{\circ} \text { Rejected }\right)\end{array}$ & $\begin{array}{l}\text { There is a low correlation between the two } \\
\text { variables }\end{array}$ \\
\hline $\begin{array}{l}\text { Length of the event with the street } \\
\text { width used }\end{array}$ & $\begin{array}{l}0.564 \\
(\text { Low) }\end{array}$ & $\begin{array}{c}0.000 \\
\left(H_{\circ} \text { Rejected }\right)\end{array}$ & $\begin{array}{l}\text { There is a low correlation between the two } \\
\text { variables }\end{array}$ \\
\hline $\begin{array}{l}\text { Reason for Place Selection with the } \\
\text { street width used }\end{array}$ & $\begin{array}{c}-0.08 \\
\text { (Ignored) }\end{array}$ & $\begin{array}{c}0.456 \\
\left(H_{\circ} \text { Accepted }\right)\end{array}$ & $\begin{array}{l}\text { There is no correlation between the two } \\
\qquad \text { variables }\end{array}$ \\
\hline $\begin{array}{l}\text { Types of Religious Days with the street } \\
\text { length used }\end{array}$ & $\begin{array}{l}-0.585 \\
(\text { Low) }\end{array}$ & $\begin{array}{c}0.000 \\
\left(\mathrm{H}_{\mathrm{o}} \text { Rejected }\right)\end{array}$ & $\begin{array}{l}\text { There is a low correlation between the two } \\
\text { variables }\end{array}$ \\
\hline $\begin{array}{l}\text { Length of the event with the street } \\
\text { length used }\end{array}$ & $\begin{array}{l}0.63 \\
\text { (Mid) }\end{array}$ & $\begin{array}{c}0.000 \\
\left(H_{\circ} \text { Rejected }\right)\end{array}$ & $\begin{array}{l}\text { There is a moderate correlation between } \\
\text { the two variables }\end{array}$ \\
\hline $\begin{array}{l}\text { Reason for Place Selection with the } \\
\text { street length used }\end{array}$ & $\begin{array}{l}0.292 \\
(\text { Low })\end{array}$ & $\begin{array}{c}0.005 \\
\left(H_{0} \text { Accepted }\right)\end{array}$ & $\begin{array}{l}\text { There is no correlation between the two } \\
\text { variables }\end{array}$ \\
\hline
\end{tabular}

\section{CONCLUSION}

Chinatown area is one of the growing urban centers because of its function as a regional trade and services in Semarang's bustling city. Aside from being a commercial area, this area is the center of ethnic Chinese religious activities, so this area is often called the temple area in 1001, because at each up the receiver, there is a pagoda that each has a privilege. The utilization of public space is dominated by economic activity and religious activity, such as the use of pedestrian ways and waterfront as a public space for street vendors and parking locations for stores that do not have a parking space. The road is also used as a location for religious activities, such as the Friday congregational prayer, the celebration of Chinese New Year, Small Sam Poo Celebrations, and Great Sam Poo Celebrations. Selection of these locations in the absence of public space that can be used for the Great Day Celebration Religious in this area, the location of the Lunar New Year celebration on the move does not reduce the interest of the community to come. Chinese New Year celebration, which is in the Gang Pinggir and Eastern Wotgandul lasted until three days three nights has a density of activity during the day and night so that a road closure. While carnival celebration small Sampoo also uses the street as a public space so that congestion takes a moment.

Outcomes from this research can be given to overcome problems that occur in activities in the public spaces are there needs to be a crowd-breaking effort at several locations with crowded locations such as Gang Warung Street, Wotgandul Timur Road, and Gang Pinggir Road using open road closing system so that side barriers and congestion can decompose. Then, the length of the religious day event is adjusted to the location used. For example, if the location of the celebration using the road corridor that has high activity should be the duration of road use as a celebration location, not too long so that no society is harmed economically. Then, informative directions are needed so that people who want to reach the event's location can easily reach the location of the celebration. It is then necessary to rearrange the location to sell goods with locations for the community to eat and enjoy snacks with community circulation to walk so that the public comfort in following the event is not disturbed. And last, there needs for the determined length of the road used during the event to avoid congestion in the Chinatown Area when religious days. The need for these recommendations is inseparable from the fact that public spaces play a large role in strengthening communities and making our cities and neighborhoods more attractive places to live and work (Rahayu, 2019). 


\section{REFERENCES}

Cohen, R. (2008). Global diasporas: An introduction. Routledge. [Crossref]

Do, D. T., Mori, S., \& Nomura, R. (2019). An Analysis of Relationship between the Environment and User's Behavior on Unimproved Streets: A Case Study of Da Nang City, Vietnam. Sustainability, 11(1), 83. [Crossref]

Evers, H.-D., \& Korff, R. (2002). Urbanisme di Asia Tenggara: Makna dan kekuasaan dalam ruang-ruang sosial. Yayasan Pustaka Obor Indonesia.

Harvey, D. (2007). A brief history of neoliberalism. Oxford University Press, USA.

Jian, L., \& Gaofeng, X. (2019). A Policy Discourse on New Town Development in Contemporary China. The City after Chinese New Towns, 59-70. [Crossref]

Kara, B. (2019). The Impact Of Globalization On Cities. Journal of Contemporary Urban Affairs, 3(2), 108-113. [Crossref]

Kim, S., \& Kwon, H. (2018). Urban sustainability through public architecture. Sustainability, 10(4), 1249. [Crossref]

Kostof, S. (1991). The city shaped: Urban patterns and meanings through history.

Kurniati, R. (2001). Spatial Pattern and Morphology District Characteristic as Urban Design Guidelines (Case Study : Semarang Chinatown District). Semarang City: Diponegoro University.

Lin, J. (1995). Ethnic places, postmodernism, and urban change in Houston. Sociological Quarterly, 36(4), 629-647. [Crossref]

Liu, M., \& Geron, K. (2008). Changing neighborhood: Ethnic enclaves and the struggle for social justice. Social Justice, 35(2 (112), 18-35.

Local Government of Semarang City. the Decree of Semarang's Mayor No.650/157. , (2005).

Mahadevia, D., \& Lathia, S. (2019). Women's safety and public spaces: Lessons from the Sabarmati riverfront, India. Urban Planning, 4(2), 154-168. [Crossref]

Mandasari, F. (2013). Analisis Karakter Kampung Pecinan di Kawasan Perdagangan dan Jasa Peunayong Pusat Kota Banda Aceh. Ruang, 1(1), 21-30.

McCartney, G., \& Chen, Y. (2019). Co-Creation Tourism in an Ancient Chinese Town. Journal of China Tourism Research, 16(2), 159-182. [Crossref]

Nguyen, V. (2011). Chinatown: The Neoliberal Remaking of Culture in the Contemporary City. Chicago: The University of Chicago.

Park, S. (2017). A preliminary study on connectivity and perceived values of community green spaces. Sustainability, 9(5), 692. [Crossref]

Prabowo, B. N., Widiastuti, R., \& Bramiana, C. N. (2017). Conservation of Semarang chinatown traditional settlement as physical characteristics of chinatown district. IOP Conference Series: Earth and Environmental Science, 99(1), 12034.

Rahayu, R. (2019). Public Open Space Policy in Kaohsiung Taiwan. Third International Conference on Sustainable Innovation 2019--Humanity, Education and Social Sciences (IcoSIHESS 2019). [Crossref]

Rahman, H., Sastrawan, A., \& Soesanti, S. (2006). Pola Penataan Zona, Massa, dan Ruang Terbuka pada Perumahan Waterfront (Studi Kasus: Perumahan Pantai Indah Kapuk). DIMENSI (Journal of Architecture and Built Environment), 34(2), 115-121.

Richards, G., \& Hall, D. R. (2003). Tourism and sustainable community development (Vol. 7). Psychology Press.

Schneider, J., \& Susser, I. (2003). Wounded cities: Destruction and reconstruction in a globalized world. Oxford. [Crossref]

Serageldin, I. (1997). The architecture of empowerment: people, shelter and livable cities. Academy Editions.

Serageldin, I., Cohen, M. A., \& Leitmann, J. (1995). Enabling sustainable community development: an associated event of the second annual conference on environmentally sustainable development. The World Bank.

Shah, N. (2019). Public Health and The Mapping of China Town. Asian American Studies Now, 168-192. [Crossref]

Soegijoko, \& Tjahjati, B. (2005). Bunga Rampai: Pembangunan Kota Indonesia Dalam Abad 21 - Konsep dan Pendekatan Pembangunan Perkotaan di Indonesia. Jakarta: Faculty of Economics, University of Indonesia.

Sugiyono. (2010). Metode Penelitian Kuantitatif, Kualitatif, dan R\&D. ALFABETA Bandung. 
Suliyati, T. (2007). Konsep Feng Shui Pada Tata Ruang Kawasan Pecinan Semarang Sebagai Respon Terhadap Aktivitas Masyarakat. Tesis. Semarang: Program Pascasarjana Universitas Diponegoro.

Thomson, M. (2019). China Town as a multilingual workplace. Stellenbosch Papers in Linguistics Plus, 56. [Crossref]

Tjahjono, G. (2014). Peran Arsitektur dan Antropologi dalam Tata Ruang Kota Indonesia Abad 21. Antropologi Indonesia. [Crossref]

United Nations Development Programme. (1999). Human Development Report. New York.

Wirotomo, P. (2004). Makalah Konstruksi Jaring Pranata Sosial Untuk Penguatan Ketahanan Sosial (Kerangka Konseptual). Jakarta.

World Development Report. (2009). Reshaping Economic Geography. Washington DC.

www.aspertina.org. (n.d.). Shejit Tjen Sien Hok Tek : Gods Of Earth.

Zimmermann, K. A. (2015). Chinese culture: Customs \& traditions of China. Live Science Retrieved from Http://www. Livescience. com/28823-Chinese-Culture. Html. Section: VIII: Appendices. 